\section{B A Institute of \\ YK Business Administration \\ 六下 \\ Karachi \\ Leadership and Ideas for Tomorrow}

Business Review

Volume 7 Issue 1 January-June 2012

$1-1-2012$

\title{
Role of marketing and construction in economic development: Lessons for emerging economies
}

\author{
Low Sui Pheng \\ National University of Singapore, Singapore \\ Dang Thuy Huong Giang \\ National University of Singapore, Singapore
}

Follow this and additional works at: https://ir.iba.edu.pk/businessreview

Part of the Growth and Development Commons, Marketing Commons, and the Real Estate Commons

\section{c) (7)}

This work is licensed under a Creative Commons Attribution 4.0 International License.

\section{Recommended Citation}

Pheng, L. S., \& Giang, D. H. (2012). Role of marketing and construction in economic development: Lessons for emerging economies. Business Review, 7(1), 6-27. Retrieved from https://doi.org/10.54784/ $1990-6587.1298$ 


\title{
ARTICLE
}

\section{Role of Marketing and Construction in Economic Development: Lessons for Emerging Economies}

\author{
Low Sui Pheng \\ National University of Singapore, Singapore \\ Dang Thuy Huong Giang \\ National University of Singapore. Singapore
}

\begin{abstract}
This paper reviews the relationship between marketing, with focus on international marketing, and economic development based on existing theoretical and empirical studies. There have been different stances on the relationship. It is, however, argued that engagement in effective marketing in general and international marketing in particular is much needed for the economic development process in most developing countries. Primary theoretical insights for government policies that support the integration of developing countries into the international market are also discussed in this paper. The paper concludes with an observation that infrastructure support provided by the construction industry is essential for trade to take off via the marketing route to spur economic development particularly in the developing countries.
\end{abstract}

Keywords: Marketing, Economic development, International trade, Infrastructure, Construction.

\section{Introduction}

Developing countries are increasingly becoming concerned with marketing management, particularly with international market issues. The connection between marketing and economic development was first recognized in the literature as early as the 1950s. Since then, there have been different stances on the relationship. The first part of this paper outlines these different perspectives and basic macro-level issues involved in marketing in the developing countries. Since the focus of this study is international marketing rather than marketing in general, the following sections of this paper will concentrate on the role of international trade and how international marketing contributes to economic development. A number of contributions to economic development are illustrated. Given the importance of international trade in economic development, integrating into international market has been becoming a critical issue for marketing management and public policy in developing countries. Hence, how governments manage trade policy, and challenges faced by national policymakers are also explored in this paper. A summary of the way for international marketing to promote economic development in developing countries concludes the paper. 


\section{Marketing and economic development}

\section{Definitions of marketing}

The early study of marketing came around the 1920s with the foundations for the Chartered Institute of Marketing (CIM) and the American Marketing Association (AMA) formed in 1911 and 1937 respectively (Agnew, 1941; CIM, 2010; Hunt, 1976). However, it was not until the 1950s that the marketing concept was born (Kinsey 1988). Popularized by McCarthy (1960) and Kotler (1967), marketing was characterized as a decision-making activity directed at satisfying the customer at a profit by targeting a market through optimal decisions on the marketing mix of price, place, promotion and product, or the "4 P's." (Vargo and Lusch, 2004). The traditional concept of marketing, which is now termed micromarketing, was closely connected to the concept of exchange or trade between producers and customers (Ferrell and Lucas, 1987). Synthesizing the early views of marketing, AMA defined marketing as "the process of planning and executing the conception, pricing, promotion, and distribution of ideas, goods, and services to create exchanges that satisfy individual and organizational objectives" (AMA Board, 1985, p.1). This concept of marketing focuses on marketing activities of individual units (firms, consumers or households). However, since the early 1960s, another trend defining marketing at a higher level of aggregation has been growing in importance in the marketing literature. Bartels (1962) argued that marketing could be broadly defined as a social activity providing for its material needs. The relationship between marketing and quality of life or gross national product was then the focus of marketing scholars during the 1970s. The broader perspective has led to the concept of macromarketing (Shawver and Nickels, 1981). Fisk (1974) defined macromarketing as a society's provisioning system. Hunt (1977) provided a more detailed definition, in which macromarketing issues are those related to (i) marketing systems; (ii) the impact and consequence of marketing systems on society; and (iii) the impact and consequence of society on marketing systems. Many later macromarketing studies based on Hunt (1977) were made in attempts to create a clearer definition of macromarketing such as those of Nickels and Hill (1978), Hunt and Burnett (1982), Fisk and Nason (1979), and Shultz, Rahtz, and Speece (2004). However, there is still no one single, uniform definition of marketing in general and macromarketing in particular within the literature (Ferrell and Lucas, 1987; Ringold and Weitz, 2007). There is only a consensus on the domain of macromarketing. While micromarketing focuses on individual exchanges and the basic unit of analysis is firms or individual customers, macromarketing emphasizes more on systems of transaction; thus its basic unit of analysis is the market system (Hunt, 1976; Mittelstaedt, J., Kilbourne, and Mittelstaedt, R., 2006). The goal of marketing from the micromarketing viewpoint is to distribute products to the satisfaction of customers and to maximize the profitability of firms, whereas the goal of marketing from the macromarketing viewpoint is to achieve the best overall interests of society in general such as efficient allocation of resources, economic growth, and general welfare of society, etc. (Bartels and Jenkins, 1977). Since this study focuses on the relationship between marketing and economic development, a macro-level perspective of marketing would be more appropriate. From that perspective, macromarketing can be defined in this study as national exchange systems which direct an economy's flows of goods and services from producers to consumers in a way which effectively matches supply and demand and accomplishes objectives of the society (Baker, 1996; Nickels and Hill, 1978). Clearly, marketing defined in this study composes of two elements: marketing discipline and marketing functions. Marketing as a discipline refers to the purpose of the national exchange system, which is to direct the economy's flows of goods and services to effectively match supply and demand, thus accomplishing objectives of the society (Fisk, 1967; Kaynak, 1982, 1984). To fulfill that task, marketing requires a functioning system as a ground to facilitate the "flows of goods and services". Even within the general category of macromarketing, the scope of marketing is still diverse and debatable, encompassing issues such as comparative 
marketing, social marketing, marketing systems, marketing research, international marketing, and commodity marketing (Hunt, 1976). A comprehensive review of the literature relating to the contentious and wide-ranging issues raised is therefore beyond the scope of this study. The subject area deserving emphasis in this study is international marketing.

Although being interpreted in a variety of ways, the term "international marketing" basically refers to any marketing activity of goods, services and information across national boundaries. The definition distinguishes international marketing from marketing in general by its cross-national nature. The distinction implies that international marketing consists of the same elements of domestic marketing but these elements are undertaken and coordinated across nations (Albaum and Peterson, 1984; Onkvisit and Shaw, 2004). International marketing operations are therefore much more complex and diverse than domestic ones (Albaum and Duerr, 2008; Cateora, 1983). The major dimensions of international marketing include: exporting, importing and management of international operations (Albaum and Duerr, 2008; Kaynak, 1984). In fact, international marketing studies focus on the solutions to numerous and complex problems associated with international trade. The main premise of international marketing is that international market transactions can be carried out more effectively to fulfill many needs left unsatisfied worldwide, and thus international marketing can improve the quality of life of individuals (Czinkota and Ronkainen, 2003). More recent international marketing studies have been viewed from multiple disciplines and integrated with perspectives from areas such as industrial organization, strategy development and anthropology (Cavusgil, 1998). Indeed, international marketing is a broad discipline encompassing many aspects of management (Bradley, 1987). It addresses a wide variety of marketing objectives and approaches (Albaum and Duerr, 2008). The focal point of this study, however, is the macroeffect of international marketing, i.e. its effect on a nation's economic development, which will be discussed further in the following sections.

\section{Perspectives on the relationship between marketing and economic development}

The interest in examining the connection between marketing and economic development was inspired by pioneering works such as those espoused by Bauer (1954) and Drucker (1958). These pioneering scholars argued that marketing played a dominant role in economic development. However, further discussions about marketing's role in the economic development process have led to different views among scholars. Studies on marketing and economic development are primarily centered on whether marketing contributes to economic development or is actually the result of increases in income and commercial goods and services (Klein and Nason, 2001). Generally, there are three dominant perspectives in the marketing and development literature: the activist, the determinist and the eclectic views. The activist school regards marketing as an agent of economic development. On the other hand, the determinist school argues that marketing is actually shaped by economic development. Meanwhile, scholars of the eclectic school believe marketing acts in both ways, passively and actively, in the economic development process (Firat, Kumcu, and Karafakioglu, 1988; Kinsey, 1988).

The activist school views marketing as the change agent that drives the economy through developmental stages (Savitt, 1988). Drucker (1958), one of the first advocates of the activist school, stressed that marketing is the most effective engine of economic development, the key element in the process of economic development. Marketing has an ability to organize and bring together resources, demands, and capacities in order to generate economic growth. In other words, marketing activities would bring about economic integration, and full utilization of productive capacity of nations. Marketing is thus indispensable to an economy (Drucker, 1958; Moyer, 1965). The multiplier effects of marketing through both its functions and philosophy is well demonstrated in the literature (Cundiff, 1965; Kinsey, 1988). 
Focusing on marketing's functions, many theorists of this school pointed out that what is needed for economic development in developing countries is an efficient marketing system, which is in turn supported by three subsystems: physical distribution system; financial system; and functional-communicative system (Drucker, 1958; Glade and Udell, 1968; Kinsey, 1988; Klein and Nason, 2001; Samli, 1978; Slater, 1968). With given resources and a production system, marketing can increase the productivity of the total economic system, increase total input of the economy by means of better and more efficient distribution system, with less waste and spoilage of goods (Samli, 1984). At the same time, with an efficient marketing system, people are exposed to a wider range of available goods. Better standards of living can also be easily spread nationwide by setting up strategic locations of wholesale and retail systems (Kinsey, 1982). Improvement of the distribution system can therefore lead to a more efficient use of existing productive resources, an increase in market size and possible economies of scale. Layton (1981), Miracle (1968) and Nurske (1971) advocated that increased competition in distribution would result in adoption of productivity enhancing innovations, thereby raising their productivity. Moreover, an improved distribution system can curb monopolistic practices, thus affecting pricing and operational efficiency (Etemad, 1984). With an efficient financial system, marketing can also increase general business efficiency as well as reduce risks associated with investing, lending and transactions. In addition, with a functional communicative system, marketing helps coordinate information between buyers and sellers in order to integrate the wants, needs, and purchasing power of the consumer with the capacity and resources of production. As a result, the functional communicative system can minimize communication time and costs of transactions, reduce searching efforts of buyers and sellers, and direct allocation of resources to the goods and services for which demand is most intense (Drucker ,1958; Fisk, 1967).

Besides marketing functions, marketing with its philosophy and techniques helps transform latent demand into effective demand, which is considered the greatest contribution of marketing in societies (Nurske, 1971). Similarly, Bartels (1977) reasoned that marketing affects behavior, attitudes, relationships, and values, thus stimulating economic development rather than just adapting to it. By encouraging entrepreneurial spirit, creating standards, developing entrepreneurs and managers, and stimulating aggregate demand, marketing enlarges market size, thereby promoting higher level of production and efficiency (Cundiff and Hilger, 1980; Kinsey, 1988; Mintz, 1968). Moreover, an orientation towards marketing thinking can contribute to better developmental planning and performance of countries in agricultural and rural development, industrial development, distribution development, foreign trade and investment development, as well as social marketing (Kotler, 1988). These activists believed that marketing techniques can be infused into developing countries through management or through multinational corporations. Multinational companies could become an important means of Western marketing knowledge transfer, technology transfer, and sources of entrepreneurial incentives (Kaynak, 1986; Kinsey, 1988; Klein and Nason, 2001).

Reviewing past studies of marketing's impact on economic development, Wood and Vitell (1986) found that profits at both the micro and macro level correlated with the nature and degree of marketing activities in less developed countries (LDCs). GDP also tended to be related to the share of the population working in marketing activities, their professional level and ability to adapt to rapid changes in the environment. Wood and Vitell (1986) explained that by changing the size of markets, concentration of markets and personal consumption patterns of consumers, marketing can affect profit realization.

As mentioned above, marketing functions and philosophy help in the distribution of outputs, and facilitate mobilization of goods and services, especially the transfer of investible resources, which is crucial for economic growth. The intangible benefits of marketing, however, often cause its key position in developing countries to be overtaken by 
other economic activities with more visible results such as manufacturing, construction and agriculture (Drucker, 1958; Wood and Vitell, 1986). In most developing countries, marketing is the least developed part of the economies (Drucker, 1958). Movement of products usually passes through multiple channel intermediaries, which are long, complex, highly fragmented and labour-intensive. Availability and quality of communication in these countries are also likely to be poor (Kinsey, 1988). Meanwhile, the lack of marketing training and education in LDCs hinders the development of entrepreneurs and managers (Wood and Vitell, 1986). The result of the lack of marketing development in these economies is their ineffective use of their limited resources (Drucker, 1958; Samli, 1978). Improvement in the marketing system and infusion of marketing techniques are therefore considered of prime importance for LDCs for the achievement of market integration and improvement (Kaynak, 1982, 1986; Kinsey, 1988).

Contrasting with the activists, the determinists argued that marketing actually plays a passive role in the economy. In other words, changes in marketing are the result of changes in economic development. As the economy develops, marketing development will follow (Cundiff and Hilger, 1982; Savitt, 1988). The scope of the determinists' studies primarily focuses on the marketing channel structures or distribution network. These studies indicated that changes in marketing channel structures reflect the stage of economic development. As the economy develops from one stage to another, new marketing institutions and new patterns of marketing channels emerge in response to the changing environment (Moyer, 1968). The environmental factors as reviewed by Savitt (1988) ranged from changes in the aggregate economic system, changes in production and technology, to changes in both economic and social factors. The determinists therefore attribute the development of marketing to changes in economic development. Hence, marketing evolves as a consequence of economic development (Bartels, 1977).

Hosley and Wee (1988) asserted that the determinists' view appears to be convincing as the evolution of many marketing institutions occurred as an outcome of adaptation to different environment. However, it overlooks the active role that marketing can play in economic development. As pointed out by Cundiff and Hilger (1982) as well as Hosley and Wee (1988), many of these instances could also dictate the reverse relationship, that is, the development of more sophisticated marketing channels causes the increase in economic development. The argument on the relationship between marketing and economic development has thus not reached any conclusive results (Cundiff and Hilger, 1982; Kaynak and Hudanah, 1987; Kinsey, 1982). According to the eclectic view, the direction of the relationship between marketing and economic development is, however, not as important as the fact that marketing is a constructive force in the process of economic development (Bartels, 1977). Advocates of the school have a distinctive view on the connection between marketing and economic development. They assert that marketing shapes and reflects changes over time as well (Dholakia and Sherry, 1987). Kinsey (1988) believed that whether marketing leads or lags behind, economic development depends on the way marketing is used, actively or passively. Meanwhile, Kaynak and Hudanah (1987) argued that marketing is dynamic, and marketing itself can stimulate economic development. The resulting influence on development, however, depends on the environmental conditions. These environmental conditions suggested by Rao (1976) consist of six basic structural dimensions: physical facilities, institutional facilities, market accessibility, technology transfer, behavioural factors, and regulations. Rao (1976) also stressed that marketing's contribution to economic development would be insignificant without the presence of these conditions and that the government could play an active role in structuring these conditions. 


\section{International marketing and economic development}

\section{Perspectives on international trade in economic development}

As mentioned earlier in this paper, the focal aspect of marketing of this study is the macro-impact of international marketing on economic development. Since exporting and importing are two major dimensions of international marketing (Albaum and Duerr, 2008; Kaynak, 1984), the macro-level impact of international marketing on economic development is closely linked with the relationship between international trade and economic development. Accordingly, the relationship between international trade and economic development is examined in this section. The connection has long been a debatable topic, notably between neoclassical trade theory and dependency theory (Hein, 1992; Mullen, 2001).

The neoclassical trade theory considers free trade as an engine of economic growth. Starting from classical theory of absolute advantage by Adam Smith (1776), the basic principle of absolute advantage suggests that both countries trading with each other can gain from trade by selling to the other what they produce more cheaply than the other. Adam Smith's trade theory thus holds that trade is a positive sum game. Refining the theory of absolute advantage, Ricardo's theory of comparative advantage (Ricardo, 1817) explained that absolute advantage was unnecessary for trade to occur. Even when both commodities may be produced more cheaply in one country than in another, trade of the commodities between the two countries can still occur. Because of differences in technology between countries, the relative efficiency among the two goods in one country is different from that in another country, thus the former will gain by exporting the good which it produces relatively more efficient to the latter and importing the one which it has least absolute advantage from the latter. The theory hence holds that all participating countries share trade gains. Different from Ricardian trade theory, the Heckscher-Ohlin theory (Ohlin, 1933), demonstrated that even when all countries have the same access to technology, costs of production between countries are still different; thus participating countries can still enjoy comparative advantage. According to the theory, comparative advantage of a country is determined by its relative abundance or scarcity of factors of production (labour, capital and land) (Flam and Flanders, 1991). Because of differences in resource endowments, a nation can produce goods that intensively use its relatively abundant resource cheaper than another, and vice versa; thus trade occurs. The essential gains from international trade of a country therefore come from the reallocation of resources from one sector to another as the country increases specialization and concentrates investments in those sectors based on comparative advantage. On the global basis, international trade can help transfer the services of factors of production from countries where these factors are abundant to countries where they are scarce, leading to positive economic growth for both exporters and importers (Bhagwati, 1990; Katsioloudes and Hadjidakis, 2007; Mullen et al., 2001). Although the Ricardian model and Heckscher-Ohlin theory are the foundation for the theory of international trade, their contributions only deal with given and static supplies of factors of production (Zhang, 2008). More recently, the contemporary trade theory argues that even countries where factors are scarce can still enjoy comparative advantages through innovation. In these countries, firms have strong incentives to make efficient use of the scarce resources and be innovative, thus creating comparative advantage (Katsioloudes and Hadjidakis, 2007). Through trade and foreign direct investment, firms can also achieve economies of scale, and acquire new knowledge and technology from abroad, thus producing more efficiently and increasing overall productivity. These long-term effects of trade on economic growth have been the focus of new trade theory and new growth theory since the early 1970s (Zhang, 2008). Overall, the important implication about the effects of trade on economic development in these theories is that through more efficient allocation of resources that enhances productivity, trade enables a nation to move beyond its production possibility frontiers, thereby acting as an engine of economic growth (Grossman and Helpman, 1991; 
Helpman and Krugman, 1985). Other developmental roles of exports and trade include increasing foreign exchange, creating employment, and improving living standard (Awokuse, 2007; Czinkota and Ronkainen, 2007; Mullen, 1993; Opara, 2010).

The dependency theory, a neo-Marxist predecessor of the world-systems theory, by contrast, argues that exporting and importing will lead to slow economic growth for the developing countries. Marxist theory (Marx 1867) holds that trade is not a positive sumgame, and capitalist countries benefit most from trade with poor countries through colonialism and imperialism (Pincus, 1967). Trade, as viewed by the dependency theory is actually a mechanism for the industrialized countries with multinational firms to extract surplus wealth from LDCs (Hein, 1992; Ram, 1985). These multinational firms invest in LDCs to produce exports but only to send the trade gains back to their home countries. By securing favorable terms of trade, the core countries (advanced industrial countries) transfer value from the peripheral countries (LDCs) rather than reinvest in these countries (Dholakia, N., and Dholakia, R., 1984; Galtung, 1971). Depending on foreign capital and markets are therefore considered as means to pave the way for multinational corporations to control LDCs to benefit their home countries, thus stifling the development in LDCs. From the theoretical perspective, the only way for LDCs to develop is to become independent of foreign capital and goods (Hein, 1992).

As a result, dependency and neoclassical trade theorists suggest extremely diverse external-trade policies for developing countries, which have been a subject of much interest in the development literature. Neoclassical trade theorists with an outward-oriented perspective suggest export-led growth development strategies; whereas the dependency theorists with an inward-oriented perspective support the import-substitution growth model. Outwardly oriented countries focus on trade liberalization (Krueger, 1990). Inwardly oriented countries, by contrast, give priority to the domestic production of goods, which could otherwise be imported from the international market (Hein, 1992). Import-substitution regimes thus employ measures such as licensing procedures, quotas, tariffs or other barriers to restrict or prohibit imports; whereas export-oriented policies generally avoid all these restrictions to permit access to the international market at international prices, at least to exporters for their inputs, and use incentives to stimulate exports to the international market. It is worthwhile to mention that an outward-oriented strategy is not necessary to be completely free-trade. There could still be elements of protection in an outward-oriented strategy as long as there is no bias of the incentive structure towards favoring the production of import substitutes (Krueger, 1990; Thirlwall, 2000).

After the Second World War, a widespread acceptance of import substitution policies as a means to stimulate economic growth developed among the developing countries, who had just obtained their independence from the colonial powers. Policy makers of these newly independent countries were impressed by the historical experience of the more developed countries where high levels of import protection had contributed positively to industrialization in the nineteenth and twentieth century (Baldwin, 2003). For example, in the 1970s, Latin American countries applied policies specifically suggested by the dependency theory, which imposed high levels of import duties and other import barriers, and maintained a hostile attitude toward foreign investment (Hein, 1992). Import substitution polices actually worked quite well initially, but only for a finite period of time. In the longer term, the drawbacks of such a policy approach became increasingly apparent. The permanent development was hampered by domestically high prices and markets for consumer and industrial goods eventually became saturated. As a result, Latin American nations experienced stagnant growth with immense external debts, high rates of inflation, shortages of investment capital, as well as the increasingly downgrading of social and economic well-being of large segments of their population (Gereffi, 1989). 
In contrast to most of Latin American countries, East Asian countries, the first group of developing countries that shifted from an inward-oriented to an outward-oriented approach to development, experienced the fastest growth of exports and gross domestic product (GDP) in the 1970s (Baldwin, 2003; Hein, 1992). The shift to export-led growth policies, especially attempts to attract foreign investment in the 1960s and 1970s of these nations have built up flexible, dynamic economies with high rates of growth (Hein, 1992). The success of the Asian newly industrializing countries (NICs) has challenged the conventional thinking of scholars and policymakers, opening new development possibilities for the developing countries. To varying degrees, a number of empirical studies across countries have also showed results in favor of outward-looking over inward-looking policies. Balassa (1971) and Little, Scitovsky, and Scott (1970) compared import substitution policies across industries and countries and recommended developing countries to reduce the average levels of effective protection, and the discrimination against exports. Bhagwati (1978) and Krueger (1978) studied changes in trade policies as well as other macroeconomic policies in specific countries. These studies concluded that it was the outward oriented, instead of inward oriented, strategy that generated long-term high growth rate for developing countries. As a result, export-led growth strategy is considered the rational and efficient alternative to import-substitution strategy for development (Awokuse, 2007). Other studies attempted to draw correlation between some measures of openness, particularly value of exports, and economic growth or productivity growth. For example, Balassa (1978), Fosu (1990) and Krueger (1978) found a significant positive relationship between growth of exports and growth of gross national product (GNP). A study by Michaely (1977) showed a positive association between per capita GNP and export share in GNP. Similarly, a number of empirical evidence have concluded the important effects of export performance, export expansion and openness to foreign markets on economic growth (Al-Yousif, 1997; Balassa, 1978, 1985; Dollar and Kraay, 2002; Feder, 1983; Islam, 1990; Kavoussi, 1984; Krueger, 1978, 1980; Moschos, 1989; Ram, 1985, 1987; Sachs et al., 1995; Salvatore and Hatcher, 1991; Tyler, 1981; Voivodas, 1973; Williamson, 1978).

There is, however, some doubt about the causality between exports, imports and economic growth in the developing economies. An empirical study by Dodaro (1993) showed a weak support for the view that export growth would promote GDP growth in LDCs. Palley (2003) was skeptical of the sustainability of export-led growth, although the focus was on global growth rather than growth of individual countries. According to the study, export-led development may work for a few countries, but it is a zero-sum game on a global basis. In other studies, Bhagwati (1988) and Krugman (1992) argued that there could be reverse causal flow from economic growth to exports growth. Productivity gains through increases in domestic levels of skilled labour and technology can lead to export expansion. Similarly, an important review by Rodriguez and Rodrik (2000) demonstrated that successful export performance could be a result of successful development rather than cause, although the study only focused on the effects of trade barriers on growth rather than on more general measures of openness. Also, there could be a bi-directional causality between exports and economic growth (Beko, 2003; Dutt and Ghosh, 1996). As explained by Dutt and Ghosh (1996), in the initial stages of development of some countries, economic growth stimulates exports, but along the way exports will lead to further economic growth. Moreover, Dutt and Ghosh (1996) believed that the causality structure depends on characteristics of a specific economy, thus it would be inappropriate to generalize the structure.

Despite the ongoing debate, the empirical evidence available indicates that no nation has ever maintained high economic growth over the long-term without trade. World interdependence is obvious (Kinsey, 1988). Opening to international competition is considered the starting point for LDCs (Dominguez, Rose, and Sequeira, 1993). The important issue for developing countries is thus not about whether to trade but should be more about how 
to trade in order to secure improvement in economic performance (Taylor, 2002; Thirlwall, 2000). The role of international marketing, as a means by which trade occurs, is therefore considered next.

\section{Role of international marketing in economic development process}

Within the macromarketing literature, international marketing has been demonstrated to play a vital role in optimizing the economic growth process. As reviewed by Dixon (1981), in the early mercantilist literature, the efficiency of product markets had already been considered to be a central factor for economic growth. These early writers maintained that with the presence of markets, countries could exchange surplus goods for the products of other countries, which are useful. The presence of an international market also allows a country to have goods that they cannot produce or can produce but with high opportunity costs compared to other countries. As explained in economic theories, trade occurs when a country owns comparative advantages of some special resources or abilities over other countries. However, it is market facilities that link a country with its international market. International marketing makes it possible for transactions between a country's productive sector and its international consumer demand. International marketing permits exporters and importers access to the international market thus enlarging the effective market size, which in turn allows greater economies of scale, and greater capacity utilization in the export sector, especially in the industries that require minimum efficient size of plant larger than the domestic market (Bhagwati, 1978; Kavoussi, 1984; Krueger, 1978; Ram, 1987). International marketing therefore fosters domestic resource allocation to be utilized effectively to the growth of both the importing and exporting countries (Opara, 2010). As countries grow, the production-efficiency focus will move toward marketing orientation, international recognition and reputation enhancement (Lee, LaPlaca, and Rassekh, 2008). More efficient marketing techniques are also adopted and created in the overall traded-goods sector. Marketing activities such as research marketing, storage and processing, packaging and retail distribution therefore become more important. Consequently, marketing activities will increase, and be more specialized. The increase in marketing activity itself, in turn, stimulates employment of labour (Dixon, 1981). The increasingly global integration of markets further enhances the critical role of international marketing in national macromarketing policy and economic development. Empirical evidence shows that those countries that deepened their integration with the global economy have achieved growth much higher than those developing countries that did not or have slowly integrated into global markets (Czinkota, Donath, and Ronkainen, 2004; Global Business Policy Council of A. T Kearney Inc., 2000; Newfarmer et al., 2002; Samli, 2002). Firms engaged in international marketing grew faster, and earned higher returns than their strictly domestic counterparts. Marketing focus, especially reputation enhancement also stimulated the international firms to improve welfare and benefits to their employees around the world. Employees in international firms have been paid higher wages. Consumers have been enjoying better quality of life from an unprecedented degree of product availability at low prices due to international competition. These countries have seen higher level of political freedom, increases in life expectancy, higher literacy rates and better overall standard of living (Czinkota and Ronkainen, 2007). The cumulative effect of all these dimensions significantly posits international marketing as a nation's economic facilitator (Opara, 2010; Samli, 1984). On a global basis, other benefits brought by international marketing linkages include improvements in labour standards, incomes and fair trade for the developing countries (The Economist, 2001; Mazur, 2000).

In spite of these achievements, the global integration of markets has not been welcomed worldwide. Opponents of international marketing criticize international marketing and suggest that there should be another way. Anti-globalization activists mainly argued that globalization threatens state democracy and intensifies inequality for the poorer participants 
in international trade flows (Taylor, 2002). However, these anti-globalization activists did not propose any sound alternative economic or social approaches (Czinkota and Ronkainen, 2003). Meanwhile, the ongoing growth and success of global integration of markets and marketing indicate that what is needed in most developing countries to make economic development realistic is to engage in effective international marketing and marketing in general (Opara, 2010). The determinants of the effective engagement into the international market are considered in the next section.

\section{International market access issues and macro-strategies for developing countries}

The integration of developing countries into the international trading system has been extensively analyzed in the past twenty years. The variables in most studies on macrostrategy at the national level include trade barriers, marketing institutions, trade liberalization and competitive advantage (Kilbourne, 2004). The first three variables have long been reviewed and analyzed in a number of papers within macromarketing, particularly in the international marketing literature. The results of these studies were used to develop negotiation as well as incentives by the international community and developing countries aimed at more effective integration of developing countries into the international economy (Hoekman, 2002; Michalopoulos, 1999a). These variables are considered to have a clear link with trade policies and market access issues for developing countries. Since trade barriers and trade protection are considered harmful for effective integration into the multilateral trading systems, most studies highlight the importance of opening up the trade system to competing traders, lowering the use of tariff and non-tariff barriers, removing exchange rate distortions, and the possible introduction of measures to reduce the impact of continuing distortions (Martin, 2001; Michalopoulos, 1999a). Integrating into the multilateral trading systems, including the World Trading Organization (WTO) also requires the developing countries to implement trading agreements governed by the WTO such as the General Agreement on Tariffs and Trade (GATT) for trade in goods, the General Agreement for Trade in Services (GATS) for trade in services, as well as other aspects of international exchange of goods and services, such as trade related intellectual property rights (TRIPS), sanitary and phytosanitary standards (SPS), government procurement, etc. (Michalopoulos, 1999b). The main challenges for developing countries are the constraints in their capacity of broad, market based institutions and those which are more specifically trade related, such as the financial sector, as well as customs and trade facilitation. Developing countries are therefore recommended to combine reducing trade barriers with other policies that are conducive to improving the investment environment, macroeconomic stability, strengthening financial, regulatory and institutional capacity with technical and financial assistance from bilateral donors and international organizations (Prowse, 2002; Rodrik, 1999; Wilson, 2001). Upgrading transport, communication and other basic infrastructure services, and building capacity to meet global regulatory requirements and standards are also important to the developing countries in order to expand trade opportunities and to effectively integrate them into the world trade system (Hoekman, 2002; Michalopoulos, 1999a, 1999b).

The macro-strategies at the national level, including the trade agreements and practices, recommended above were generally based on the comparative advantage doctrine (Samli and Jacobs, 1995). However, more recently, it is argued that comparative advantage may not provide the complete answer for the development of an efficient export sector; and a more coherent strategy may lie in competitive advantage (Dominguez, Rose, and Sequeira 1993; Lowinger, Lal, and Arunthanes, 1995). The competitive advantage model was proposed by Porter (1990). Porter's (1990) analysis was based on the premise that the national competitive environment in which firms operate can considerably influence the international competitive performance of firms. The competitiveness of nations viewed by Porter (1990) 
is the ability of a nation to create and maintain such an environment that shapes highlycompetitive industries and firms. Firms built in such a national environment can be more successful when they export or engage in outward foreign direct investment (Rugman and D'Cruz, 1993). Reviewing Porter's (1990) work, Grant (1991) as well as Katsioloudes and Hadjidakis (2007) briefly listed elements of a national environment that play important roles in firms' competitive performance within the world market as follows:

- Factor conditions (i.e., the nation's position in factors of production, especially advanced factors of production such as skilled labor, capital and infrastructure);

- Demand conditions (i.e., sophisticated and demanding customers in the domestic market);

- Related and supporting industries (i.e., the importance of clustering industries and spillover benefits of an industry's investments in advanced factors of production within these clusters); and

- Firm strategy, structure, and rivalry (i.e., the characteristics of the business sector as conditions for organization of companies, and the nature of domestic rivalry).

Porter (1990) integrated the four primary conditions into a diamond-shaped diagram with two exogenous parameters, namely government and chance. The four contextual variables operate interdependently and their strength of interaction determines the extent to which a national environment is conducive to international success. A nation is therefore viewed as a set of contextual variables which can hinder or support the competitive performance of firms and industries (Grant, 1991). As a result, the macro strategy through which government can have the most direct effect in the competitive development process involves policies that support research and development, investments in human resource development, and infrastructure renovation and development (Dominguez, Rose, and Sequeira, 1993; Samli and Jacobs, 1995).

While Porter's (1990) framework at the country-level has become the emphasis within the management school, it has been ignored by the economics school. Recent studies within the economic literature argue that Porter's (1990) framework is not about trade; it cannot explain the pattern of trade and gains from trade, and thus cannot replace the theory of comparative advantage (Smit 2010). Nevertheless, Porter's (1990) detailed analysis has offered an unprecedentedly broad range of national-level sources of competitive advantage and brought them together in a comprehensive model for formulating government strategy (Grant, 1991; Moon, Rugman, and Verbeke 1998; Rugman and D'Cruz 1993). Moreover, within the marketing literature, the use of Porter's (1990) diamond framework has been discussed and considered as a good starting paradigm for greater optimization of national efforts to achieve success in international markets (Moon, Rugman, and Verbeke, 1998; Samli and Jacobs, 1995).

The importance of developing countries in the world economy is increasing. However, only a few of the higher income developing countries have impressively integrated into the multilateral trading system. The progress of many other developing countries has been much slower (Hoekman, 2002; Michalopoulos, 1999a). Although assistance from the international community is important for the progress, these developing countries' own policies are even more crucial. In the context of growing complexity and interdependence of foreign trade policies, designing and sustaining supporting policies are challenging tasks (Hoekman, 2002; Jordana and Ramió, 2003). The following section will examine the role of institutional structure in the formulation of foreign trade policy at the national level. 


\section{Trade Policy Institutions}

Using international trade as a vehicle for a country's development strategy requires the country to open up and liberalize trade, which represents a change of direction in long term development strategy, and involves a new leading role for trade policy. Engagement with and into the multilateral trading systems also makes trade policy far more complex, which create pressures to reinforce the trade policy process and the strategic management capacity in the main organization responsible for trade-policy making (Jordana and Ramió, 2003; Rodrik, 2002). Institutional structure and the formulation of foreign trade policy at the national level are considered critical elements for an efficient trade policy process (Devlin and Estevadeordal, 2003; Hoekman, 2002; Lecomte, 2003; Sinha, 2007). As a result, there is a growing need for governments in developing countries where institutional performance remains weak to introduce further changes into their existing institutional models.

Responding to the above mentioned challenges, there have been efforts in many developing countries to renew and adapt themselves to the demands of the new international environment. Transformation of institutional structure is often characterized by giving greater power to the core ministry dealing with trade (Jordana and Ramió, 2003). For example, the power and status of India's Ministry of Commerce has been radically enhanced recently, in part to attempt to further export its products and services aggressively and to engage the WTO more actively. The growing complexity of trade policy also necessitates the involvement of, or the integration with, other government ministries in the policy process such as the Ministry of Foreign Affairs, Ministry of Industry or Ministry of Agriculture (Sinha, 2007). The inclusion of all actors, including the relevant ministries, trade promotion and regulatory bodies, and nongovernmental players from the business sector, think tanks, independent research centers, leading universities and other civil society organizations is also considered part of the institutional transformation (Lecomte, 2003). However, introducing changes into an organizational model is not a trivial task. Moreover, different conditions in each country require a specific institutional design. In many developing countries, performance has not been improved satisfactorily. Trade policy formulation and implementation in these countries are still dominated by governmental and inter-governmental agencies with overlapping functions and deficient coordination (Jerome, 2005; Jordana and Ramió, 2003). The conflict between ministries in foreign trade policy making leads to a strong need for the establishment of an inter-ministerial coordination body in some countries such as the International Economic Negotiations Inter-ministerial Committee in Chile, the Higher Council and a technical system of committees in Columbia, and the Trade Negotiations Committee in the Dominican Republic (Jordana and Ramió, 2003). In other countries, the coordination task is given to a core ministry such as the Ministry of Commerce in India (Sinha, 2007). In addition to coordinating trade policies across various ministries, the coordination body can also have consultation with non-government players to complement the decision making process with particular interests of specific societal and business players, and ensure that national interests prevail. These complementary changes in the existing institutional structure and improvements in institutional capacity are thus vital if trade liberalization is to serve as an engine of growth.

\section{Conclusion}

The relationship between marketing and economic development varies in the literature. Two traditional schools appear to contradict each other over the role of marketing in economic development. The activists viewed marketing as a facilitator of economic development. Meanwhile, the determinists maintained that the opposite is true, i.e. marketing is shaped by economic development. Adopting a neutral position, the eclectic school believed marketing can act in both a passive and active manner in economic development. Similarly, 
there is no consensus on the macro-level impact of international marketing on economic development in the literature. International trade, a major dimension of international marketing, is considered an engine of economic growth in the neoclassical economic trade theory. This conflicts with the dependency theory, in which international trade is viewed as a hindrance to economic development. A summary of the major theoretical insights of the relationship are shown in Figure 1 (See Appendix). Kotler's (1967) ubiquitous 4P's model is also included in Figure 1 to help place the entire spectrum relating to marketing in perspective.

However, focusing more on the empirical perspective, a number of studies have shown a positive association between export expansion and openness to foreign markets, and economic development. Although there is still some doubt about the causality of the relationship, trade between nations is believed to play a crucial role in the economic development process. Thus, as a means by which trade occurs, international marketing is considered an economic facilitator. It is international marketing that links a country with its international market, and drives domestic resource allocation to be utilized effectively. As a result, what is needed for economic development in most developing countries is to engage in effective international marketing.

Effective integration into the international market or the world trading system requires a liberal trade policy using traditional policy instruments such as tariffs, quotas, export subsidies, and taxes, complemented by trade-related institutions to facilitate trade and attain national objectives. The growing complexity of the trade agenda necessitates the involvement of all actors, including relevant ministries, as well as other governmental and nongovernmental bodies, thus demanding greater institutional capacity as well as greater internal coordination. Given the weak institutional performance in many developing countries, further changes and improvement in the institutional structure and capacity of trade policy making are thus vital for economic growth.

A more recent suggested trade agenda covers a broader focus on such policies as those involving research and development, human resources development, as well as infrastructure renovation and development. The doctrine has important implications for infrastructure development and its role in international trade. Within the general marketing literature, it is also believed that the resulting influence of marketing on development depends on the environmental conditions, including physical facilities (Kaynak and Hudanah, 1987; Rao, 1976). The push for economic development through marketing, particularly in the context of international trade, cannot take off without the necessary infrastructural support provided by the construction industry. There have been a number of empirical studies addressing the issue of inadequate infrastructure that hinder export earnings in developing countries (Batra, 1997; Nwankwo, 2000; Morrissey and Rudaheranwa, 1998). The issue is also getting attention even in the more developed countries. Britain, for instance, has in 2010 set aside a $£ 200$ billion plan to improve the national infrastructure as a means to stimulate exports and economic growth (Straits Times, 2010). Infrastructure development in turn depends to a large extent on the capacity of the construction sector. This suggests the need to synchronize marketing's contributions in economic development with appropriate infrastructural construction support. The relationship between construction and marketing should collectively be considered in economic development to better facilitate more balanced growth.

\section{Further Discussions}

The review presented above outlines different perspectives on the role of marketing in general, and the role of international marketing in particular in economic development. A focus on international market access issues in developing countries has indicated the need 
to maintain, renovate and develop the infrastructure system in these countries. Infrastructure maintenance, renovation and development in turn depend to a large extent on the capacity of the construction sector. The arguments presented in this paper illuminate the need for related government agencies to coordinate construction and marketing in the economic development process of developing countries. The case thus suggests a broader approach to place the coordination in perspective as a factor of economic development. The analysis presented in this review will be particularly useful for researchers in international business, marketing and construction to adopt a wider strategic outlook in order to map out and stress the importance of timely coordination between marketing and construction. In this context, it would be worthwhile to further discuss the following questions:

- How is the relationship between marketing and construction to be initiated?

- Through whom can these two sectors be coordinated strategically in a timely fashion?

- What changes must occur in the coordinating process in order to create the positive aspects?

- Does the change occur automatically? If not, how can this be facilitated?

The examination of these questions is meaningful for policy making that addresses the issues of inadequate and poor quality of the infrastructure delivered by the construction industry to support trade growth in emerging economies.

\section{References}

Agnew, H. E. (1941). The History of the American Marketing Association. The Journal of Marketing, 5(4), 374-379.

Al-Yousif, Y. K. (1997). Exports and economic growth: some empirical evidence from the Arab Gulf countries. Applied Economics, 29(6), 693-697.

Albaum, G. and Duerr, E. (2008). International Marketing and Export Management. New York: Prentice Hall.

Albaum, G. and Peterson, R. A. (1984). Empirical research in international marketing: 19761982. Journal of International Business Studies, 15(1), 161-173.

AMA Board. (1985). AMA Board Approves New Marketing Definition. Marketing News, 19(5), 1 .

Awokuse, T. O. (2007). Causality between exports, imports, and economic growth: Evidence from transition economies. Economics Letters, 94(3), 389-395.

Baker, M. J. (1996). Marketing: An Introductory Text. Hampshire: Macmillan Basingstoke.

Balassa, B. A. (1971). The Structure of Protection in Developing Countries. Baltimore: The Johns Hopkins Press.

Balassa, B. A. (1978). Exports and economic growth: Further evidence. Journal of Development Economics, 5(2), 181-189.

Balassa, B. A. (1985). Exports, policy choices, and economic growth in developing countries after the 1973 oil shock. Journal of Development Economics, 18(1), 23-35.

Baldwin, R. E. (2003, March) Openness and growth: What's the empirical relationship? , NBER Working Paper. Cambridge, MA: National Bureau of Economic Research.

Bartels, R. (1962). The Development of Marketing Thought. Homewood, IL: R.D. Irwin. 
Bartels, R. (1977). Marketing and economic development. In C. C. Slater (Ed.), MacroMarketing: Distributive Processes from a Societal Perspective (pp. 211-217). Boulder: Business Research Division, University of Colorado.

Bartels, R. and Jenkins, R. L. (1977). Macromarketing. The Journal of Marketing, 41(4), 17-20.

Batra, R. (1997). Marketing issues and challenges in transitional economies. Journal of International Marketing, 5(4), 95-114.

Bauer, P. T. (1954). West African Trade: A Study of Competition, Oligopoly and Monopoly in a Changing Economy. Cambridge: Cambridge University Press.

Bekõ, J. (2003). Causality Analysis of Exports and Economic Growth: Aggregate and Sectoral Results for Slovenia. Eastern European Economics, 41(6), 70-92.

Bhagwati, J. N. (1978). Foreign Trade Regimes and Economic Development: Anatomy and Consequences of Exchange Control Regimes. Cambridge, MA: Ballinger.

Bhagwati, J. N. (1988). Protectionism. Cambridge, MA: MIT Press.

Bhagwati, J. N. (1990). Export-promoting trade strategy: issues and evidence. In C. Milner (Ed.), Export Promotion Strategies: Theory and Evidence from Developing Countries (pp. 11-39). London: Harvester Wheatsheaf.

Bradley, M. F. (1987). Nature and significance of international marketing: A review. Journal of Business Research, 15(3), 205-219.

Cateora, P. R. (1983). International Marketing. Homewood, IL: R.D. Irwin. Cavusgil, S. T. (1998). Knowledge development in international marketing. Journal of International Marketing, 6(2), 103-112.

CIM. (2010). History. Retrieved October 30, from

Cundiff, E. W. (1965). Concepts in comparative retailing. The Journal of Marketing, 29(1), 59-63.

Cundiff, E. W. and Hilger, M. T. (1980). Marketing and the Production-Consumption Thesis in Economic Development. In G. Fisk, R. W. Nason \& P. D. White (Eds.), Macromarketing: evolution of Thought (pp. 177-186). Boulder: University of Colorado, Business Research Division.

Cundiff, E. W. and Hilger, M. T. (1982). The Consumption Function: Marketing's Role in Economic Development. Management Decision, 20(4), 36-46.

Czinkota, M. R., Donath, B. and Ronkainen, I. A. (2004). Mastering Global markets: Strategies for today's Trade Globalists. Mason, OH: Thomson/Southwestern.

Czinkota, M. R. and Ronkainen, I. A. (2003). An international marketing manifesto. Journal of International Marketing, 11(1), 13-27.

Czinkota, M. R. and Ronkainen, I. A. (2007). International Marketing (8th ed.). Mason, OH: Thomson South-western.

Devlin, R., Estevadeordal, A. and Bank, I.-A. D. (2003). Bridges for Development: Policies and Institutions for Trade and Integration. Washington, DC: Inter-American Development Bank.

Dholakia, N. and Dholakia, R. R. (1984). Missing links: Marketing and the newer theories of development. In G. S. Kindra (Ed.), Marketing in Developing Countries (pp. 57-75). New York: St. Martin Press. 
Dholakia, N. and Sherry, J. (1987). Marketing and development: a resynthesis of knowledge. In J. N. Sheth (Ed.), Research in marketing (Vol. 9, pp. 119-143). Greenwich Connecticut: JAI Press.

Dixon, D. F. (1981). The role of marketing in early theories of economic development. Journal of Macromarketing, 1(2), 19-27.

Dodaro, S. (1993). Exports and growth: a reconsideration of causality. The Journal of Developing Areas, 27(2), 227-244.

Dollar, D. and Kraay, A. (2002). Growth is Good for the Poor. Journal of Economic Growth, $7(3), 195-225$.

Dominguez, L., Rose, P. and Sequeira, C. (1993). Environmental and managerial factors in export-led development: an explorative test of Porter's competitive advantage of nations. Journal of Macromarketing, 13(2), 5-21.

Drucker, P. F. (1958). Marketing and economic development. The Journal of Marketing, 22(3), 252-259.

Dutt, S. D. and Ghosh, D. (1996). The export growth-economic growth nexus: a causality analysis. The Journal of Developing Areas, 30(2), 167-182.

Etemad, H. (1984). Is Marketing the Catalyst in the Economic Development Process? In G. S. Kindra (Ed.), Marketing in Developing Countries (pp. 29-56). London: Croom Helm.

Feder, G. (1983). On exports and economic growth. Journal of development economics, 12(1-2), 59-73.

Ferrell, O. C. and Lucas, G. H. (1987). An Evaluation of Progress in the Development of a Definition of Marketing. Journal of the Academy of Marketing Science, 15(3), 12-23.

Firat, A. F., Kumcu, E. and Karafakioglu, M. (1988). The Interface between Marketing and Development: Problems and Prospects. In E. Kumcu (Ed.), Marketing and Development: Toward Broader Dimensions (Vol. Supplement 4, pp. 317-343). Greenwich, Connecticut: JAI Press.

Fisk, G. (1967). Marketing Systems: An Introductory Analysis. New York: Harper and Row. Fisk, G. (1974). Marketing and the Ecological Crisis. New York: Harper \& Row. Fisk, G. and Nason, R. W. (Eds.). (1979). Macro-marketing: New Steps on the Learning Curve. Boulder: University of Colorado Business Research Division.

Flam, H. and Flanders, M. J. (1991). Heckscher-Ohlin Trade Theory. Cambridge, MA: The MIT Press.

Fosu, A. K. (1990). Exports and economic growth: the African case. World Development, 18(6), 831-835.

Galtung, J. (1971). A structural theory of imperialism. Journal of Peace Research, 8(2), 81117.

Gereffi, G. (1989). Rethinking development theory: insights from East Asia and Latin America. Sociological Forum, 4(4), 505-533.

Glade, W. and Udell, J. G. (1968). The Marketing Behaviour of Peruvian Firms: Obstacles and Contributions to Economic Development. In R. Moyer \& S. C. Hollander (Eds.), Markets and Marketing in Developing Economies (pp. 153-169). Homewood, Ill.: R. D. Irwin.

Global Business Policy Council of A. T Kearney Inc. (2000). Globalization Ledger. Retrieved from http://www.atkearney.de/content/misc/wrapper.php/name/file_globalization_ledger_1 067976422bca9.pdf 
Grant, R. M. (1991). Porter's 'Competitive advantage of nations': an assessment. Strategic Management Journal, 12(7), 535-548.

Grossman, G. M. and Helpman, E. (1991). Innovation and Growth in the Global Economy. Cambridge, Mass.: MIT Press.

Hein, S. (1992). Trade strategy and the dependency hypothesis: a comparison of policy, foreign investment, and economic growth in Latin America and East Asia. Economic Development and Cultural Change, 40(3), 495-521.

Helpman, E. and Krugman, P. R. (1985). Market Structure and Foreign Trade: Increasing Returns, Imperfect Competition, and the International Economy. Cambridge, Mass.: MIT Press.

Hoekman, B. (2002). Strengthening the global trade architecture for development: the post Doha agenda. World Trade Review, 1(01), 23-45.

Hosley, S. and Wee, C. H. (1988). Marketing and economic development: Focusing on the less developed countries. Journal of Macromarketing, 8(1), 43-53.

Hunt, S. D. (1976). The nature and scope of marketing. The Journal of Marketing, 40(3), $17-28$

Hunt, S. D. (1977). The three dichotomies model of marketing: An elaboration of issues. In C. C. Slater (Ed.), Macromarketing: Distributive Processes from a Societal Perspective (pp. 52-56). Boulder, CO: Business Research Division, University of Colorado.

Hunt, S. D. and Burnett, J. J. (1982). The macromarketing/micromarketing dichotomy: a taxonomical model. The Journal of Marketing, 46(3), 11-26.

Islam, N. (1990). Horticultural Exports of Developing Countries: Past Performances, Future Prospects, and Policy Issues. Washington, DC: International Food Policy Research Institute.

Jerome, A. (2005). Institutional Framework and the Process of Trade Policy Making in African: The Case of Nigeria. Paper presented at the International conference "African Economic Research Institutions and Policy Development: Opportunities and Challenges", Dakar, January 28-29.

Jordana, J. and Ramió, C. (2003). Trade policy institutions: Comparative analysis. In R. Devlin \& A. Estevadeordal (Eds.), Bridges for Development: Policies and Institutions for Trade and Integration (pp. 179-201). Washington, DC: Inter-American Development Bank.

Katsioloudes, M. I. and Hadjidakis, S. (2007). International Business: a Global Perspective. Burlington, MA: Butterworth Heinemann.

Kavoussi, R. M. (1984). Export expansion and economic growth: Further empirical evidence. Journal of development economics, 14(1), 241-250.

Kaynak, E. (1982). Marketing in the Third World. New York: Praeger.

Kaynak, E. (1984). Current Status of International Marketing Management. In E. Kaynak (Ed.), International marketing management (pp. 3-21). New York: Praeger.

Kaynak, E. (1986). Marketing and Economic Development. New York: Praeger.

Kaynak, E. and Hudanah, B. I. (1987). Operationalising the relationship between marketing and economic development: some insights from less-developed countries. European Journal of Marketing, 21(1), 48-65.

Kilbourne, W. E. (2004). Globalization and development: An expanded macromarketing view. Journal of Macromarketing, 24(2), 122-135. 
Kinsey, J. (1982). The role of marketing in economic development. European Journal of Marketing, 16(6), 64-77.

Kinsey, J. (1988). Marketing in Developing Countries. London: Macmillan Education Ltd.

Klein, T. A. and Nason, R. W. (2001). Marketing and development: macromarketing perspectives. In P. N. Bloom \& G. T. Gundlach (Eds.), Handbook of marketing and society (pp. 263-297). Thousand Oaks, Calif.: Sage Publications, Inc.

Kotler, P. (1967). Marketing Management: Analysis, Planning and Control. Englewood Cliffs, NJ: Prentice Hall.

Kotler, P. (1988). Potential Contributions of Marketing Thinking to Economic Development. In A. F. Firat \& E. Kumcu (Eds.), Marketing and Development: Toward Broader Dimensions, Supplement 4 of Research in Marketing (pp. 1-10). Greenwich, Connecticut: JAI Press.

Krueger, A. O. (1978). Foreign Trade Regimes and Economic Development: Liberalization Attempts and Consequences. Cambridge, MA: Ballinger.

Krueger, A. O. (1980). Trade policy as an input to development. The American Economic Review, 70(2), 288-292.

Krueger, A. O. (1990). Perspectives on Trade and Development. New York: Harvester Wheatsheaf.

Krugman, P. R. (1992). Import protection as export promotion: International Competition in the Presence of Oligopoly and Economies of Scale. In G. M. Grossman (Ed.), Imperfect Competition and International Trade (pp. 75-86). Cambridge, MA: MIT Press.

Layton, R. A. (1981). Trade Flows in Macromarketing Systems: Part IA Macromodel of Trade Flows. Journal of Macromarketing, 1(1), 35-48.

Lecomte, H. B. S. (2003, November) Building Capacity to Trade: What Are the Priorities? In OECD (Series Ed.), Working Paper: Vol. 223. Paris: OECD.

Lee, J., LaPlaca, P. and Rassekh, F. (2008). Korean Economic Growth And Marketing Practice Progress: A Role Model For Economic Growth Of Developing Countries. Industrial Marketing Management, 37(7), 753-757.

Little, I. M. D., Scitovsky, T. and Scott, M. F. (1970). Industry and Trade in some Developing Countries: a Comparative Study. New York: Oxford University Press.

Lowinger, T. C., Lal, A. K. and Arunthanes, W. (1995). Foreign access to the Japanese market: Structural and economy-wide factors. Journal of Macromarketing, 15(2), 50-65.

Martin, W. (2001, January) Trade policy reform in the East Asian transition economies. Policy Research Working Paper: Vol. 2535. Washington, DC: The World Bank.

Mazur, J. (2000). Labor's new internationalism. Foreign Affairs, 79(1), 79-93.

McCarthy, E. J. (1960). Basic Marketing: A Managerial Approach. Homewood, IL: Richard D. Irwin.

Michaely, M. (1977). Exports and growth: an empirical investigation. Journal of Development Economics, 4(1), 49-53.

Michalopoulos, C. (1999, October ) Trade policy and market access issues for developing countries: implications for the Millennium Round. World Bank Policy Research Working Paper: Vol. 2214. Washington DC.: World Bank.

Michalopoulos, C. (1999, September) The integration of transition economies into the world trading system. Policy Research Working Paper: Vol. 2182. Washington, DC: World Bank. 
Mintz, S. W. (1968). Peasant market places and economic development in Latin America. In R. Moyer \& S. L. Hollander (Eds.), Markets and Marketing in Developing Economies (pp. 170-189). Homewood, Ill.: R. D. Irwin.

Miracle, M. P. (1968). Market Structure in Commodity Trading and Capital Accumulation in West Africa. In R. Moyer \& S. C. Hollander (Eds.), Markets and Marketing Developing Economies (pp. 209-227). Homewood, IL: R. D. Irwin.

Mittelstaedt, J. D., Kilbourne, W. E. and Mittelstaedt, R. A. (2006). Macromarketing as agorology: Macromarketing theory and the study of the agora. Journal of Macromarketing, 26(2), 131-142.

Moon, H. C., Rugman, A. M. and Verbeke, A. (1998). A generalized double diamond approach to the global competitiveness of Korea and Singapore. International Business Review, 7(2), 135-150.

Morrissey, O. and Rudaheranwa, N. (1998) Ugandan trade policy and export performance in the 1990s. CREDIT discussion paper: Vol. 6. Nottingham: University of Nottingham, Centre for Research in Economic Development and International Trade.

Moschos, D. (1989). Export expansion, growth and the level of economic development: An empirical analysis. Journal of development economics, 30(1), 93-102.

Moyer, R. (1965). Marketing in Economic Development. Michigan: Michigan State Uiversity, East Lansing.

Moyer, R. (1968). International market analysis. Journal of Marketing Research, 5(4), 353360.

Mullen, M. R. (1993). The effects of exporting and importing on two dimensions of economic development: An empirical analysis. Journal of Macromarketing, 13, 3-19.

Mullen, M. R., Beller, E., Remsa, J. and Cooper, D. (2001). The effects of international trade on economic growth and meeting basic human needs. Journal of Global Marketing, 15(1), $31-55$.

Newfarmer, R., Timmer, H., Varoudakis, A., Mattoo, A., Fink, C., Maskus, K., et al. (2002, July 25, 2010). Global economic prospects and the developing countries 2002: Making trade work for the world's poor. Retrieved July 25, 2010, from

Nickels, W. G. and Hill, R. (1978). Is Marketing What the Textbooks Say?-New Definitions of Macro and Micro Marketing. In C. C. Slater (Ed.), Macro-marketing: Distributive Processes from a Societal Perspective, An Elaboration of Issues. Boulder: University of Colorado Business Research Division.

Nurske, R. (1971). The Theory of Development and the Idea of Balanced Growth. In A. B. Mountjoy (Ed.), Developing the Underdeveloped Countries (pp. 115-128). New York: John Wiley.

Nwankwo, S. (2000). Assessing the marketing environment in sub-Saharan Africa: opportunities and threats analysis. Marketing Intelligence \& Planning, 18(3), 144-153.

Ofori, G. (1990). The Construction Industry: Aspects of its Economics and Management. Singapore: NUS Press.

Ohlin, B. G. (1933). Interregional and international trade. Cambridge: Harvard university press.

Onkvisit, S. and Shaw, J. J. (2004). International marketing: Analysis and strategy. London: Routledge. 
Opara, B. C. (2010). Export Marketing: Catalyst for Nigeria Economic Paradigm Shift. Research Journal of International Studies, 13(March, 2010), 79-87.

Palley, T. I. (2003). Export-Led Growth: Evidence of Developing Country Crowding-out. In P. Arestis, M. Baddeley \& J. S. L. McCombie (Eds.), Globalisation, Regionalism and Economic Activity (pp. 175-197). Cheltenham: Edward Elgar.

Pincus, J. A. (1967). Trade, Aid and Development: the Rich and Poor Nations. New York: McGraw-Hill.

Porter, M. E. (1990). The Competitive Advantage of Nations. New York: Free Press.

Prowse, S. (2002). The Role of International and National Agencies in Trade-related Capacity Building. World Economy, 25(9), 1235-1261.

Ram, R. (1985). Exports and economic growth: some additional evidence. Economic Development and Cultural Change, 33(2), 415-425.

Ram, R. (1987). Exports and economic growth in developing countries: evidence from timeseries and cross-section data. Economic Development and Cultural Change, 36(1), 51-72.

Rao, T. R. (1976). Marketing and Economic Development. Marketing and Management Digest, 8(1), 17.

Ricardo, D. (1817). On the principles of political economy, and taxation. London: J. M'Creepy.

Ringold, D. J. and Weitz, B. (2007). The American Marketing Association definition of marketing: Moving from lagging to leading indicator. Journal of Public Policy \& Marketing, 26(2), 251-260.

Rodriguez, F. and Rodrik, D. (2000). Trade policy and economic growth: a skeptic's guide to the cross-national evidence. NBER macroeconomics annual, 15, 261-325.

Rodrik, D. (1999). The New Global Economy and Developing Countries: making Openness Work. Washington, DC: Overseas Development Council.

Rodrik, D. (2002). Trade Policy Reform as Institutional Reform. In B. Hoekman, A. Mattoo \& P. English (Eds.), Development, Trade, and the WTO: a Handbook (pp. 3-10). Washington, DC: The World Bank.

Rugman, A. M. and D'Cruz, J. R. (1993). The "double diamond" model of international competitiveness: The Canadian experience. Management International Review, 33(2), 17 39.

Sachs, J. D., Warner, A., Åslund, A. and Fischer, S. (1995). Economic reform and the process of global integration. Brookings Papers on Economic Activity, 1995(1), 1-118.

Salvatore, D. and Hatcher, T. (1991). Inward oriented and outward oriented trade strategies. Journal of Development Studies, 27(3), 7-25.

Samli, A. C. (1978). Marketing and Distribution Systems in Eastern Europe. New York: Praeger.

Samli, A. C. (1984). Role of Marketing in Economic Development: What Should International Marketers Know? In E. Kaynak (Ed.), International Marketing Management (pp. 34-50). New York: Praeger.

Samli, A. C. (2002). In Search of An Equitable, Sustainable Globalization: the Bittersweet Dilemma. Westport, Conn.: Quorum Books. 
Samli, A. C. and Jacobs, L. (1995). Achieving congruence between macro and micro generic strategies: A framework to create international competitive advantage. Journal of Macromarketing, 15(2), 23-32.

Savitt, R. (1988). The State of the Art in Marketing and Economic Development. In E. K. a. A. F. Firat (Ed.), Marketing and Development: Toward Broader Dimensions, Supplement 4 of Research in Marketing (pp. 11-38). Greenwich, Connecticut: JAI Press.

Shawver, D. L. and Nickels, W. G. (1981). A rationalization for macromarketing concepts and definitions. Journal of Macromarketing, 1(1), 8.

Shultz, C. J., Rahtz, D. R. and Speece, M. (2004). Globalization, transformation, and quality of life: Reflections on ICMD-8 and participative marketing and development. Journal of Macromarketing, 24(2), 168.

Sinha, A. (2007). Global Linkages and Domestic Politics: Trade Reform and Institution Building in India in Comparative Perspective. Comparative Political Studies, 40(10), 11831210 .

Slater, C. C. (1968). Marketing processes in developing Latin American societies. The Journal of Marketing, 32(3), 50-55.

Smit, A. J. (2010). The Competitive Advantage of Nations - is Porter's Diamond Framework a New Theory that Explains The International Competitiveness of Countries. Southern African Business Review, 14(1), 105-130. Retrieved from

Smith, A. (1776). An Inquiry into the Nature and Causes of the Wealth of Nations. New York: Oxford University Press.

Taylor, A. M. (2002, November) Globalization, Trade, and Development: Some Lessons from History. Vol. w9326. NBER working paper. Cambridge, MA: National Bureau of Economic Research.

The Economist. (2001, September 19). Globalisation and its critics. The Economist, 360(8241), 3-5.

The Straits Times. (2010, October 26). British PM: Today's pain is tomorrow gain. The Straits Times, p. A20.

Thirlwall, A. P. (2000) Trade, trade liberalisation and economic growth: theory and evidence. Economic Research Paper: Vol. 63.

Turin, D. A. (1969). The Construction Industry: its Economic Significance and Its Role in Development. London: University College, Environmental Research Group.

Tyler, W. G. (1981). Growth and export expansion in developing countries: Some empirical evidence. Journal of Development Economics, 9(1), 121-130.

Vargo, S. L. and Lusch, R. F. (2004). Evolving to a new dominant logic for marketing. Journal of marketing, 68(1), 1-17.

Voivodas, C. S. (1973). Exports, foreign capital inflow and economic growth. Journal of International Economics, 3(4), 337-349.

Wells, J. (1985). The role of construction in economic growth and development. Habitat International, 9(1), 55-70.

Williamson, R. B. (1978). The role of exports and foreign capital in Latin American economic growth. Southern Economic Journal, 45(2), 410-420. 
Wilson, J. S. (2001). Bridging the Standards Divide: Recommendations for Reform from a Development Perspective. Washington, DC: World Bank

Wood, R. V. and Vitell, S. J. (1986). Marketing and economic development: Review, synthesis, and evaluation. Journal of Macromarketing, 6(1), 28-47.

Zhang, W. B. (2008). International Trade Theory: Capital, Knowledge, Economic Structure, Money, and Prices Over Time. Germany: Springer Verlag.

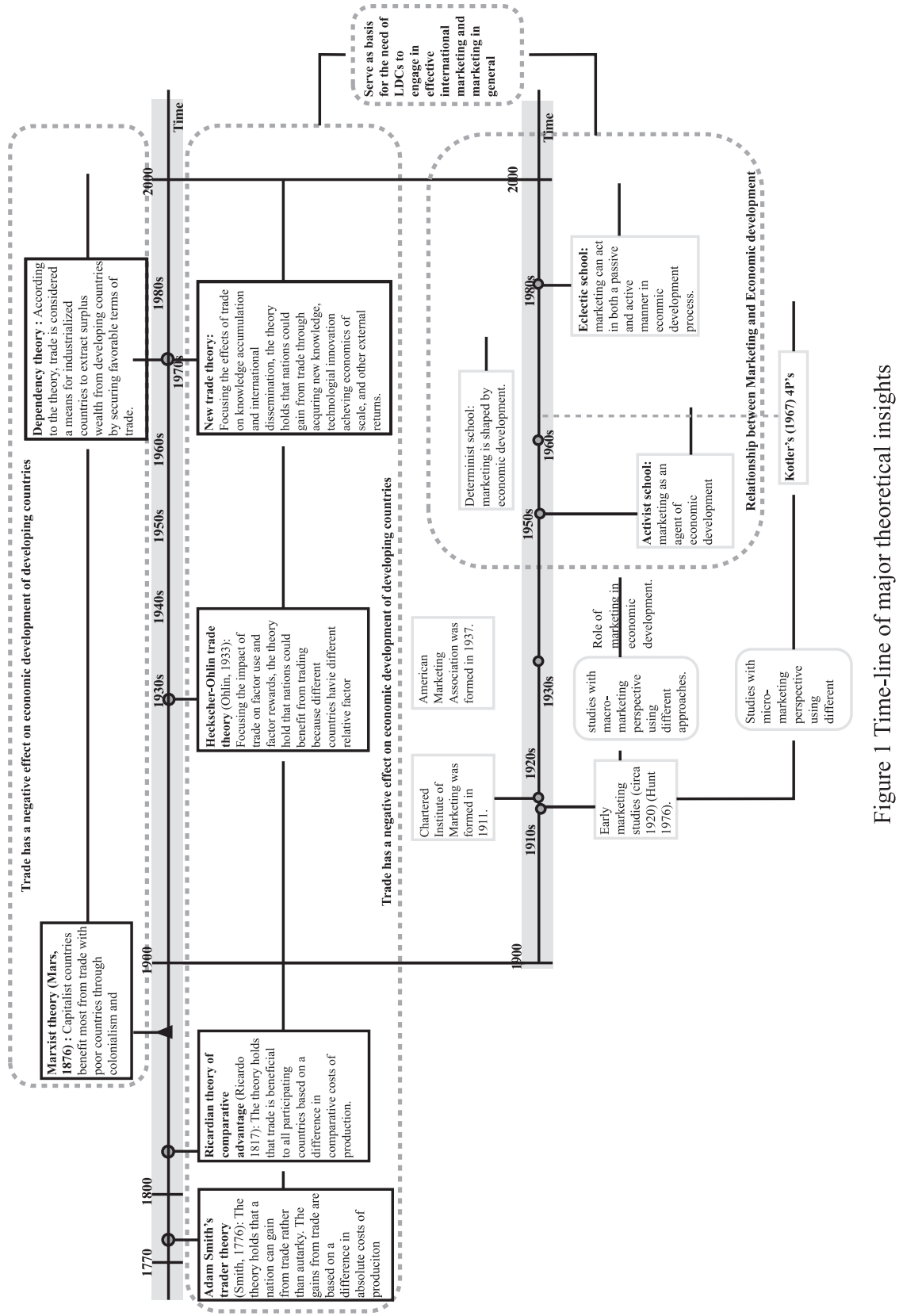

